in.
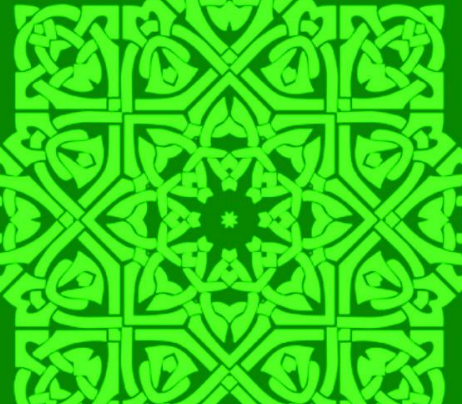

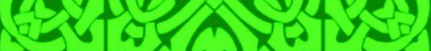

4es

w

(4)

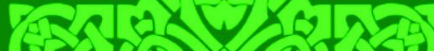
पर (15) (0) जि tr

10

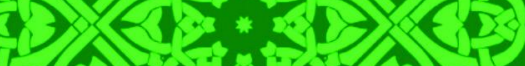

(e)

रत 2000

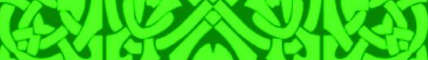

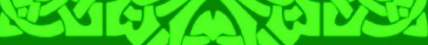

प्रा

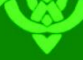

(4)

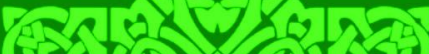

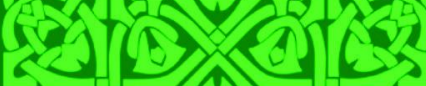

Cᄂ

20

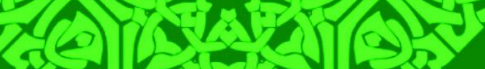

o 21 . 50

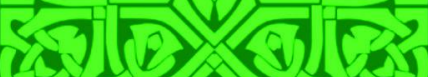

zots $x$ -

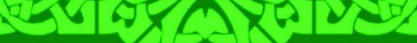

पis

4

Vol 19. No $2 / 2019$
Muhammad Syahran

Al-Islām min Al-Ta'ālīm Ilā Al-Taṭbìqāt, Musykilat Al-Jisr Al-

Maqtu'

Abbas

Salafi and Social Religion Dynamics In Kendari

Muhammad Tahir Alibe, Abdul Muiz Amir

The Infallibility of The Prophet Muhammad Pbuh. As A Human Being (A Study Of His Ijtihad)

Muhammad Saleh Tajuddin The Role of Abdurrahman Wahid in Creating Islamic PostTraditionalist Paradigm in Indonesia

Muh Ilham Usman Islam and Agrarian: Study of Nahdhatul Ulama's Religious Social Thought

Tasmin Tangngareng, Hasbullah A Prophetic Study On Earthquake

Usman Jafar Muslims' Thoughts of Non-Muslims' Political Rights in Majority Muslim Areas in Makassar 


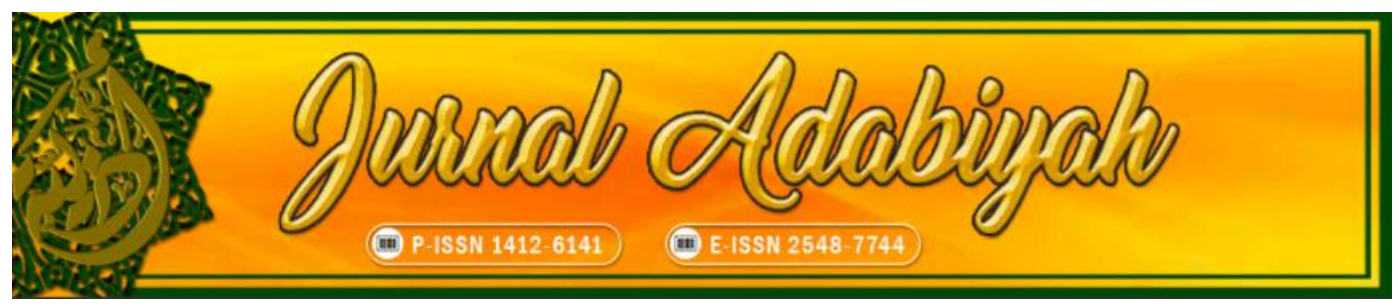

Thema: Islamic Studies

VOLUME 19 NO. 2 DESEMBER 2019

EDITOR-IN-CHIEF

Barsihannor, Alauddin State Islamic University, Indonesia

INTERNATIONAL EDITORIAL BOARD

Nuri Emmiyati, Alauddin State Islamic University, Indonesia

Minako Sakai, Australian National University (ANU), Australia

Abd Rauf Muhammad Amin, Fakulti Syariah Kupu SB Brunei Darussalam, Brunei Darussalam

Muhammad Zakir Husain, Universiti Islam Sultan Sharif Ali, Brunei Darussalam

Muhammad Widus Sempo, Universiti Sains Islam Malaysia, Malaysia

Salih Yousif Sharaf Mohamed, Al-Gazera University, Sudan

Aishah Waenaha Waemamah, Academy of Islamic and Arabic Studies Princess of Naradhiwas University - Thailand, Thailand

EXECUTIVE EDITOR

Umar Thamrin, Universitas Islam Negeri Alauddin, Indonesia

MANAGING EDITOR

Zaenal Abidin, Universitas Islam Negeri Alauddin

\section{EDITORS}

Rosmah Tami, Alauddin State Islamic University, Indonesia

Haniah, Alauddin State Islamic University, Indonesia

Nasrum, Alauddin State Islamic University, Indonesia

Awaluddin Syamsu, Universitas Muslim Indonesia

Ahmadi Usman, UIN Syarif Hidayatullah Jakarta, Indonesia

Baso Pallawagau, Alauddin State Islamic University, Indonesia Muhammad Azwar, Universitas Islam Negeri Syarif Hidayatullah Jakarta, Indonesia

Muh. Saleh Syamsuri, Alauddin State Islamic University, Indonesia

Andi Satrianingsih, Muhammadiyah University, Indonesia

Syahruni Junaid, Alauddin State Islamic University, Indonesia

Rabiatul Adawiah, Majene Islamic State College, West Sulawesi, Indonesia, Indonesia

Chusnul Chatimah Asmad, Alauddin State Islamic University, Indonesia

Nur Arifin, Alauddin State Islamic University, Indonesia

\section{IT SUPPORT}

Taufiq Mathar, Alauddin State Islamic University, Indonesia

\section{LANGUAGE ADVISOR}

Kustiwan Syarief, UIN Syarif Hidayatullah Jakarta, Indonesia

Muh. Saleh Syamsuri, Alauddin State Islamic University, Indonesia

\section{COVER DESIGNER}

Nur Arifin 


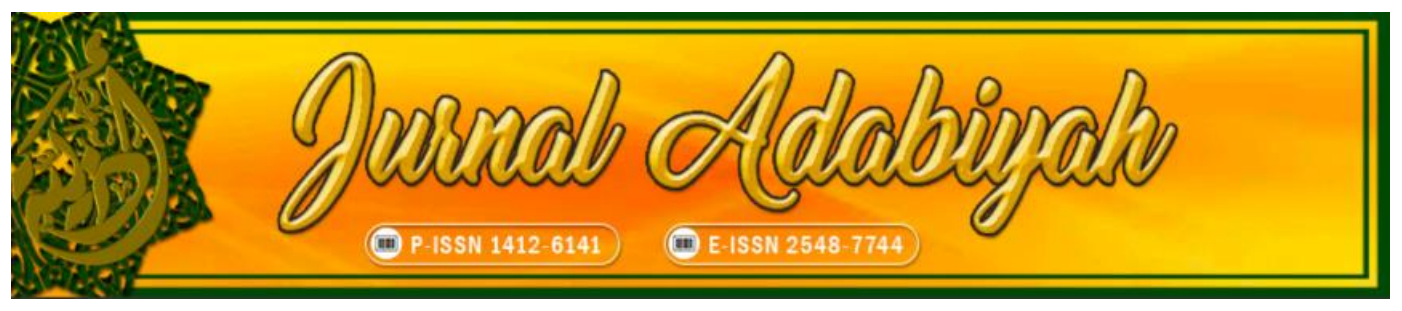

\section{Jurnal Adabiyah:}

This journal receives a national accreditation from Ministry of Research, Technology, and Higher Education Republic of Indonesia, Nomor 10/E/KPT/2019 on April 4, 2019 with the SINTA score: S2.

The Journal has been published by the Faculty of Adab and Humanity of Alauddin State Islamic University, Makassar, since 1997 and has been online since 2016 with the main themes on Humanities and Islamic Studies with the emphasis on interdisciplinary and intertextuality approach.

This journal are published twice a year, on June and December. The themes related to Islamic Studies are textual studies, scriptural traditions, Islamic law, and theology; and those related to Humanities are language, literature, history, and culture.

The journal of Humanities and Islamic Studies will provide the online collection of articles from 1997 up to now. The most updated information can be found on the website. 


\section{Table of Contents}

Muhammad Syahran

103-121

Al-Islām min Al-Ta'ālìm Ilā Al-Tațbīqāt, Musykilat Al-Jisr Al-Maqț'

Abbas

$122-136$

Salafi and Social Religion Dynamics in Kendari

Muhammad Tahir Alibe, Abdul Muiz Amir

137-156

The Infallibility of The Prophet Muhammad Pbuh. As A Human Being

(A Study Of His Ijtihad)

Muhammad Saleh Tajuddin

157-171

The Role of Abdurrahman Wahid in Creating Islamic Post-Traditionalist Paradigm in Indonesia

Muh Ilham Usman

172-185

Islam and Agrarian: Study of Nahdhatul Ulama's Religious Social Thought

Tasmin Tangngareng, Hasbullah

186-203

A Prophetic Study on Earthquake

Usman Jafar.

204-223

Muslims' Thoughts of Non-Muslims' Political Rights in Majority Muslim Areas in Makassar 


\title{
SALAFI AND SOCIAL RELIGION DYNAMICS IN KENDARI
}

\author{
Abbas \\ Institut Agama Islam Negeri Kendari \\ abbas@iainkendari.ac.id / abbastekeng@gmail.com
}

\begin{abstract}
This article reveals the existence of the salafi community with its various social and religious effects as a new phenomenon of religious diversity in Kendari. Since the presence of the Islamic Center Muadz bin Jabal, the social and religious life of Kendari has indicated some shifts both socially and culturally. Since this issue has not been explored, it is aimed at providing an overview of the existence of ICM as salafi community and its implications for society in a comprehensive manner. This research is qualitative research with a sociological approach with functional and interactional theories. This study shows that the ICM as salafi community has a big influence on presenting new religious phenomenon. They have taken over some religious stages which have been dominated by old communities such as NU and Muhammadiyah, reinforced by the presence of their mass media. The thoughts of salafi, which were initially opposed, began to be accepted by the public and the government, for the salafi in Kendari is generally tolerant, socializing, and adaptable. although there are small groups that are still extreme and less tolerant.
\end{abstract}

Keywords: Salafi; social transformation; Islamic Center Muadz bin Jabal; Kendari;

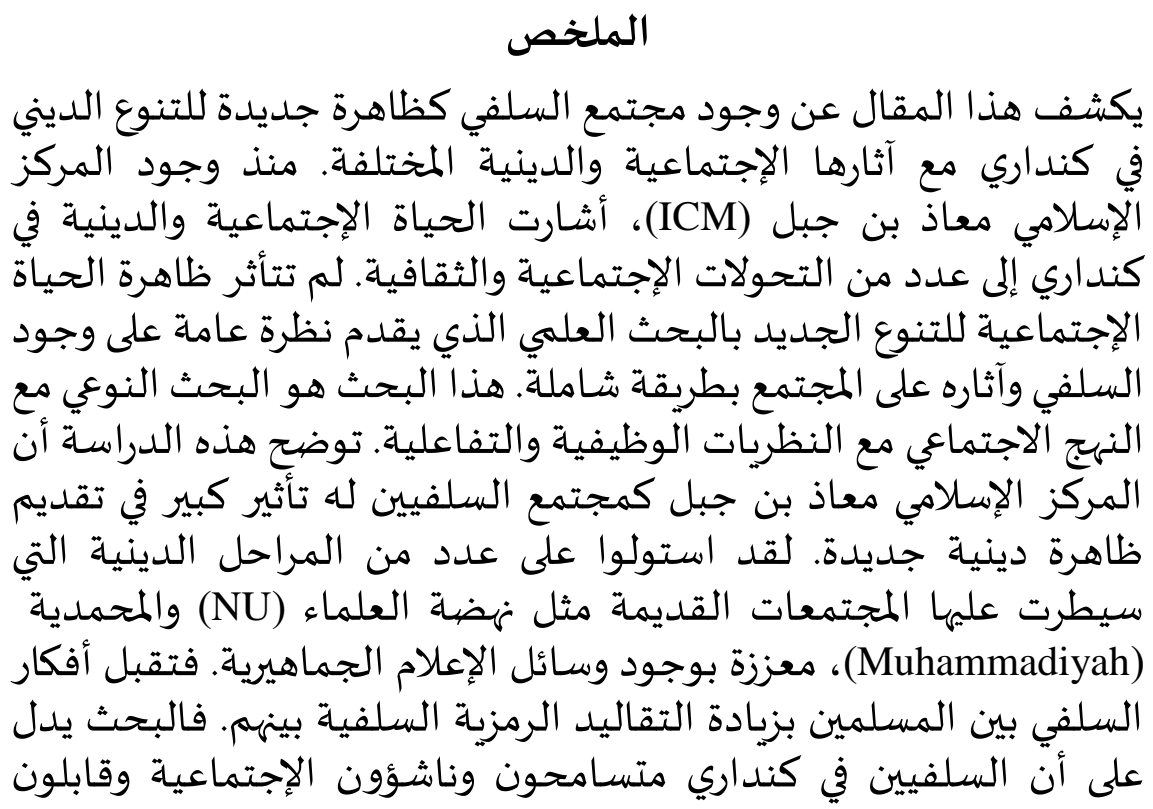




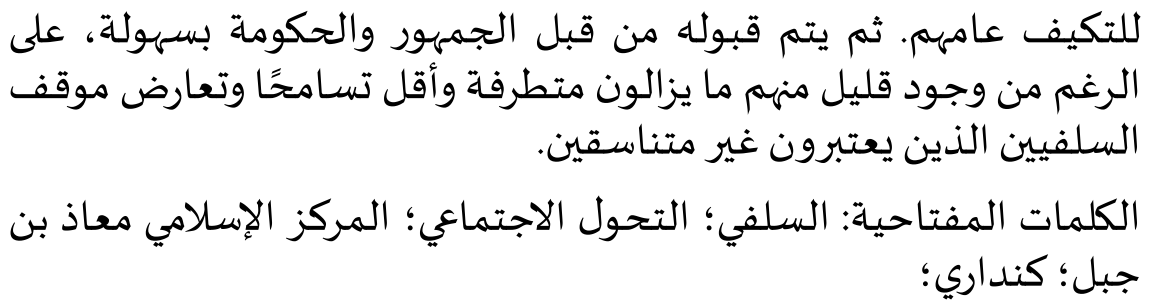

\begin{abstract}
Abstrak
Kajian ini bertujuan untuk mengungkap eksistensi komunitas salafi sebagai sebuah fenomena keberagamaan baru Kota Kendari dengan berbagai efek sosial keagamaan yang ditimbulkannya. Sejak hadirnya institusi Islamic Center Muadz bin Jabal (ICM), kehidupan sosial keagamaan masyarakat Kota Kendari terindikasi telah terjadi sejumlah pergeseran sosial kultural. Fenomena kehidupan sosial keberagamaan wajah baru tersebut belum tersentuh penelitian ilmiah yang memberikan gambaran eksistensi komunitas ICM sebagai salafi dan implikasinya terhadap masyarakat secara komprehensif. Penelitian ini adalah sebuah penelitian kualitatif dengan pendekatan sosiologi dengan teori fungsional dan interaksional. Penelitian ini menunjukkan bahwa ICM sebagai komunitas salafi telah mewarnai Kota Kendari. Para ustadz dan pembina mereka telah banyak berkiprah dan mengambil alih sejumlah panggung keagamaan yang selama ini dikuasai oleh komunitas lama seperti NU dan Muhammadiyah, diperkuat oleh kehadiran media radio dan tv mereka. Paham-paham salafi yang awalnya banyak ditentang masyarakat mulai diterima dan tidak dipersoalkan lagi, bahkan tradisi simbolik salafi seperti memakai jubah dan memperpanjang jenggot semakin marak di masyarakat. Penelitian ini menemukan bahwa salafi di Kota Kendari secara umum toleran, bersosialisasi, beradaptasi dan lebih terbuka sehingga mudah diterima masyarakat bahkan pemerintah, meski terdapat kelompok kecil yang masih ekstrim dan kurang toleran bahkan tidak menerima sikap salafi lainnya yang dianggap tidak konsisten terhadap manhaj salafi
\end{abstract}

Kata Kunci: Salafi; Transformasi sosial; Islamic Center Muadz bin Jabal; Kendari

\title{
A. Introduction
}

The phenomenon of salafi pesantren in Indonesia has become an exciting trend in pesantren, religious, and even Indonesian studies. The presence of some salafi pesantren, a name they give to themselves, is an implication of the entry of transnational flow into Indonesia that embodies the dynamics of the pesantren in a quite complicated way. Salafi pesantrens which are claimed as unindigenous pesantrens strive to build and develop themselves amidst indigenous pesantren that 
have existed long before. They are identified as unindigenous since the salafi pesantren no longer represent the characteristics of indigenous (traditional) Indonesian pesantren called the salaf/salafiyah pesantren with their classical text, turā $\dot{s} .^{1}$

The categorization of pesantren into pesantren salaf and khalaf (traditional and modern) is problematic since it obscures the use of the term salafi in the traditional sense that idealizes the generation of șalaf al-șälih (early Islamic generations) as opposed to khalafi in the modern sense, a term that is also inaccurately associated with Wahhabis and terrorists. ${ }^{2}$

Religious and social discourse in Indonesia is exciting to observe because of the presence of some new problems in the community both between Muslims themselves and with the government, and often lead to communal conflicts in various regions. ${ }^{3}$ Salafis oriented towards puritanism or purification of religion by teaching the ideology of the salaf generation (the first three generations after the death of the Prophet Muhammad) ${ }^{4}$ must deal with social and religious realities where the public understands and practices religious teachings which are also considered to be accurate based on the teachings of the previous sects.

The salafism movement in Kendari began in the early 2000s since the establishment of a pesantren educational institution called the Pondok Pesantren Minhajussunnah as a pioneer of the Salafi pesantren in Kendari. Salafi flow then developed with the inclusion of the Wahdah Islamiyah community organization in 2006. ${ }^{5}$ However, the new chapter began in 2008 after the establishment of an educational institution called the Islamic Center Muadz bin Jabal (starting now referred to as ICM) which was allegedly carrying the understanding of salafi and had a significant influence on the dynamics of the socio-religious life of the Kendari City community.

A number of studies carried out on ICM, for example the Asliah Zainal study, et al entitled "The Pattern of Education and Da'wah Pattern of Islamic Center Muadz bin Jabal (ICM) in Kendari City" which focuses on the existence of ICM as an educational institution and $d a^{\prime} w a h$ institution with its strategy that win interest Kendari City community. ${ }^{6}$ Another study by Nur Alim, et al. entitled "Singularity of

${ }^{1}$ Muhammad Misbah, 'Tradisi Keilmuan Pesantren Salafi', IBDA ' Jurnal Kajian Islam dan Budaya, Vol. 12, no. 2 (2014), p. 241-258.

${ }^{2}$ Mark Woodward, 'Modeling Muslim Social Movements : A Case Study of Indonesian Salafism', in Annual Conference on Islamic Studies Banjarmasin Indonesia, 2011, pp. 1-16.

${ }^{3}$ Mukhtar Hadi, 'Fenomena Kelompok Keagamaan Baru (Heresy) Dalam Islam (Studi Terhadap Jama'ah Ittiba' Al -Salaf Di Purwoasri Metro Utara)', Ri'ayah, Vol. 2, no. 2 (2017), p. 1-19.

${ }^{4}$ Mukhtar Hadi, 'Fenomena Kelompok Keagamaan Baru (Heresy) Dalam Islam (Studi Terhadap Jama'ah Ittiba’ Al -Salaf Di Purwoasri Metro Utara)', Ri'ayah, Vol. 2, no. 2 (2017), p. 1-19.

${ }^{5}$ Saprillah Syahrir, 'The Islamic Centre of Muadz Bin Jabal of Kendari', JICSA, Vol. 6, no. 2 (2017), p. 295.

${ }^{6}$ Zainal, Suud and Zainal, 'Pola Pendidikan dan Pola Dakwah Islamic Centre Muadz Bin Jabal (ICM) di Kota Kendari', Al-Izzah: Jurnal Hasil-Hasil Penelitian, Vol. 12, no. 2 (2018), p. 44-66. 
Religion; Identification of Flow and Radical Understanding in Kendari" which identifies the ICM and Wahdah Islamiyah as a non-radical movement because their religious thinking and nationality did not lead to radical teachings and terrorism. Specifically, for ICM, Nur Alim's research acknowledges the focus on education and da'wah. Moreover, Saprillah's research entitled "The Islamic Center of Muadz bin Jabal of Kendari" further emphasizes the position of the ICM as a religious education institution by describing the pattern of movements in religious education and ICM religious understanding itself. Saprillah assesses that the salafi movement in Kendari has a bright future because they carry out routine coaching and maximize the potential for spreading propaganda through many media, in addition to useful approaches and collaboration with the government. ${ }^{7}$

Some studies on ICM that have been stated, but this study has a different purpose and focus because of this research aimed at examining the socio-religious dynamics that are especially happening in society. It is undeniable that religious understanding can have social implications for people's lives because religious life is part of social life itself. Therefore, the significance of this research is to uncover some changes in the pattern of the socio-religious life of the Kendari City community as an effect of the presence of the ICM, both from tradition and ritual and other social effects.

\section{B. Method}

This research is qualitative descriptive research using naturalistic concepts, meaning that they are under social situations, as there are data in the field that are experienced, felt, and thought by participants/data sources. The theory of social change in the sociological approach of Burhan Bungin can be classified in the form of changes in thought patterns, behavior changes, and cultural changes. Changes in mindset and attitudes towards society in various social and cultural issues will give birth to a new mindset adopted by society as a modern attitude. While changes in people's behavior involve changes in social systems where people leave the old system and switch to a new system. While material culture changes involve changes in cultural artifacts used by the community such as clothing models and photography works. ${ }^{8}$

This research used sociology as an approach by functional and interactional theories. Although there are several theories in social research, researchers use functional and interactional theories because they are both relevant to salafi social phenomena in Kendari as a contestation of roles, functions, and interactions in society.

${ }^{7}$ Saprillah Syahrir, 'The Islamic Centre of Muadz Bin Jabal of Kendari', JICSA, Vol. 6, no. 2 (2017), p. 295-331.

${ }^{8}$ Burhan Bungin, Sosiologi Komunikasi; Teori, Paradigma Dan Diskursus Teknologi Komunikasi Di Masyarakat, IV (Jakarta: Kencana Prenada Media Group, 2009), p. 91-92. 


\section{Salafi and the Islamic Center Muadz bin Jabal (ICM) in Kendari}

Salafi is a term for a group or group of salaf followers. The naming of salafis, according to their adherents, is a necessity because these claims confirm their status as followers of the right and survivors represented by the salaf generation (some others call the salaf al-șälih). The word salaf has initially been only attributed to the three early generations of Islam namely sahabah (companions)-, tābi 'in and tābi 'altābi i $\bar{i}$. The meaning of the word salaf then developed because in the first three generations the sect split occurred, so that the meaning of orientation was no longer limited to the meaning of qudwah (exemplary) in these three generations, but also meant manhaj (method), ie anyone who followed the method and understanding of the three main generations the. Therefore, salaf is interpreted as a generation of companions, tābi'īn and tābi 'al-tābi'īn, as well as all Muslims who follow their footsteps until the Day of Judgment, where their justice and cleanliness are recognized in ijma' and not accused of bidding 'ah which causes kufr and wickedness. $^{9}$

As a religious movement, the Salafi group has characteristics and characteristics that distinguish it from other Islamic movements. Based on Bernard Haykel's theory, Salafi has several unique and distinctive characteristics, including ${ }^{10}$ :

First, the majority of salafis are not political actors. They are not political activists who form political parties or organizations. In fact, they do not have a formal organization that has political targets or power to be achieved. This makes the salafi movement free to move.

Second, the occurrence of social and religious reforms is a significant concern. The emergence of religious awareness is so strong at the individual level that it will then form a robust religious awareness community. Individual religious awareness is so strong, in the long run, it will have indirect implications for politics. Therefore, the Salafi group seeks to form a group that bases itself on the foundation of religion (theology). They want to change with Islamic $d a^{\prime} w a h$ from the very bottom of society and starting from the individual level and personal transformation. The hope for a change of religion from the small will form a more religious system.

Third, salafi can be identified from how they dress, their religious behavior, how they pray and how they speak. This is a manifestation of the emergence of an awareness of carrying out religious orders. Fourth, emphasizing to refer to the Qur'an and Hadith. They always prioritize strong arguments before committing an act. Therefore, mastery of Arabic is emphasized. The emphasis on tauhid in the study is a prominent feature of salafis. Although the study was given non-politics, namely the issue of monotheism, the discussion may touch the political realm, for example talking about a political system dominated by many layers of authority when understanding a text, and this is what distinguishes other Muslim traditions, so that interpretation is more open and democratic.

${ }^{9}$ Mu'tab bin Suryan Al-'Ashimi, Beda Salaf Dengan Salafi (Solo: Media Islamika, 2007).

${ }^{10}$ Bernard Haykel, Revival and Reform in Islam: The Legacy of Muhammad Al-Shawkani (UK: Cambridge University Press, 2003) p. 24-37. 
Fifth, they have a limited hierarchy in understanding Islamic teachings. This means that in seeking the basics of religion to strengthen belief $\bar{l}$ without passing through a complicated hierarchy. They can obtain direct sources textually without having to go through several deep personal hierarchies. This is where they cut down the many layers of authority when understanding a text, and this is what distinguishes it from other Muslim traditions so that the interpretation is more open and democratic.

Sixth, it is not limited by territory and also not fundamentalist. The nonlimitation of the territory is the main attraction for the majority of the people. Even moderate attitudes and not identical to the thoughts of fundamentalists, further strengthen the attractiveness of many parties. Therefore, the movement of the Salafi people crossed the world boundary and developed everywhere as a transnational movement.

Seventh, they always base all behavior and views by referring to texts originating from revelations, the Qur'an and the Hadith. An empirical example, they are very obedient to the government and have never criticized openly.

The above salafi criteria automatically become the identity of the salafi pesantren, so that the salafi pesantren is associated with Wahhabism. Therefore, salafi pesantren are characterized by several characteristics, namely as a purification movement, with their campaign back to the Qur'an and Sunnah, and with their exclusive impression. With this character, salafi groups or pesantren are identified with 'hard-line' groups, fundamentalists, revivalists, scriptualists, textualists, Islamists, and fanatics. ${ }^{11}$

Salafis are identical to religious sects, not as organizations. Therefore, they are not united by separate organizations and have many variants. In the Middle East, salafì followers even have at least five groups namely Salafïyyūn Surūriyyūn, Salafìyyūn Al-Albāniyyūn, Salafìyyūn al-Jam'iyyūn, Salafìyyūn followers of Shaykh 'Abd al-Rahmān' Abd al-Khāliyūn in Kuwait, Salafìyyūn al-Jam'iyyūn, Salafìyyūn followers of Shaykh 'Abd al-Raḥmān' Abd al-Khālik in Kuwait, Salafìyyūn Shaykh 'Uśaimin in Saudi Arabia. The Salafìyyūn Surūriyyūn was assigned to the Syrian preacher Muhammad Surur Zain al-Abidin was a political salafi group influenced by the Muslim Brotherhood. Salafìyyūn Al-Albāniyyūn is attributed to Al-Albānī who is concerned with fighting fiery fanaticism and rejecting imitation. Salafìyūn alJam 'iyyün is a hard salafi congregation and tends to blame and attack opposing groups. ${ }^{12}$

In the Indonesian context, the Salafi movement is largely influenced by the ideas and movements of reform carried out by Muhammad bin 'Abd al-Wahhāb in the Arabian Peninsula region. According to Abū 'Abd al-Raḥmān al-Ṭālibī, the idea of renewal Ibn 'Abd al-Wahhāb was allegedly first brought into the archipelago by

\footnotetext{
${ }^{11}$ Muhammad Misbah, 'Tradisi Keilmuan Pesantren Salafi', IBDA' : Jurnal Kajian Islam Dan Budaya, Vol. 12, no. 2 (2014), p. 248-249.

${ }^{12}$ M. Imdadun Rahmat, Arus Baru Islam Radikal Transmisi Revivalisme Islam Timur Tengah ke Indonesia (Jakarta: Erlangga, 2005), p. 10.
} 
several scholars from West Sumatra at the beginning of the XIX century. ${ }^{13}$ The reform movement in Indonesia is originally a movement better known as the Padri movement; one of the main characters is Tuanku Imam Bonjol. This movement itself took place in 1803 until around 1832. ${ }^{14}$ However, Ja'far Umar Thalib claims in one of his writings that this movement emerged during the time of the Sultan of Aceh Iskandar Muda (1603-1637). ${ }^{15}$

In general, the typology of the salafi movement is divided into three based on the Quintan Wiktorowicz theory of 'purist', 'politico', and 'jihadi'. ${ }^{16}$ Whereas Zoltan Pall criticized it and offered two categories namely 'purist' and 'haraki'. ${ }^{17}$ However, Din Wahid, combining two theories, classifies three typologies of Salafi movement namely 'purist', 'haraki', and 'jihadist', and 'purist' are classified into three sub-groups namely 'rejectionists', 'cooperasionits', and 'tanzimi'. ${ }^{18}$

The perceptions of the Indonesian people in each region who have received previous schools or teachings with the culture of the Nahdatul Ulama and Muhammadiyah have again questioned these differences because they only followed a school with traditions passed down without reason and arguments so that what existed became taklid and hard to change. On the other hand, young groups are anxious with various questions, and it is easier to accept and practice them because they look only at the aspects of non-academic doctrine and academic doctrine without comparison with the previous schools. other groups also have academic doctrines as a basis for strong comparisons so that they do not respond to new doctrines.

Salafi in Kendari is claimed to have been present since 2000 through the Minhajussunnah education movement, then Wahdah Islamiyah in 2006, the Ahlus Sunnah Wal Jamaah group, and increasingly varied since the presence of the Islamic Center of Muadz bin Jabal in 2008. ${ }^{19}$ The ICM is indicated to adhere to the notion of salafi from their principle of making the Qur'an and Sunnah the primary reference in education and da'wah as exemplified by the Salafussalih. Salafussalih or the generation of early Islam which is considered to be the generation of Islamic ideals is

${ }^{13}$ Abu Abdirrahman Al Thalibi, Dakwah Salafiyah Dakwah Bijak: Meluruskan Sikap Keras Dai Salafi (Jakarta: Hujjah Press, 2006), p. 30-31.

${ }^{14}$ Muradi, Gerakan Paderi Di Sumatera Barat (Jakarta: Logos, 1999), p. 84.

${ }^{15} \mathrm{Ja}$ 'far Umar Thalib, 'Pasang Surut Menegakkan Syariah Islamiyah', Majalah SALAFY, Vol. $5,664-702$.

${ }^{16}$ Quintan Wiktorowicz, 'Anatomy of the Salafi Movement', Studies in Conflict and Terrorism, Vol. 29, no. 3 (2006), p. 207-39.

${ }^{17}$ Mira Baz, 'Lebanese Salafis between the Gulf and Europe: Development, Fractionalization and Transnational Networks of Salafism in Lebanon', Islam and Christian-Muslim Relations, Vol. 25, no. 1 (2014), p. 134-36.

${ }^{18}$ Din Wahid, 'Nurturing Salafi Manhaj A Study of Salafi Pesantrens in Contemporary Indonesia', Wacana, Vol. 15, no. 2 (2015), p. 367.

${ }^{19}$ Saprillah Syahrir, 'The Islamic Centre of Muadz Bin Jabal of Kendari', JICSA, Vol. 6, no. 2 (2017), p. 295 
the keyword for all the salafi movements. However, ICM does not want to be called salafi because of the negative stigma over the label salafi which is associated with radicalism and terrorist background, so they refer to themselves as Ahlussunnah Wal Jamaah. $^{20}$

ICM officials claim that ICM is not a religious organization such as NU, Muhammadiyah, Hizb ut-Tahrir, or Wahdah Islamiyah. ICM does not have an organizational structure except the foundation structure. ICM does not have a regeneration system to recruit new members. ICM also does not implement a membership system that binds all followers as part of group identity. Therefore, ICM does not have a membership list, cadre recruitment patterns, and does not have areabased management. Existing administrators are only foundation administrators who work within a limited scope. People who are recruited as administrators are people who have a close relationship with Ustadz Zezen or people who are considered potential to develop ICM programs. ${ }^{21}$

H. Zezen Zaenal Mursalin as the ICM leader of Kendari has explained the achievements of ICM since it was inaugurated by the Mayor of Kendari in October 2008. Among them is the preaching cadre education program, the establishment of the Muadz 94.3 FM radio, SMS of daily da'wah that has served around 16 thousand members, organizing social religious activities such as mass circumcision, sacrifice, to corpse services with ICM ambulance facilities.

The achievement of ICM so far is the result of the consistency of the da'wah that was carried out from its inception. In about four years, ICM already has a permanent congregation with hundreds of people, where at the beginning of its establishment ICM only had dozens of people. Over time the number of recitation worshipers increased to over 200 people who became permanent worshipers (for male brothers/sisters), and there were around 40 people (sisters/female worshipers). Radio and television media also made a significant contribution in this regard, Radio Muadz bin Jabal 94.3 FM, for example inviting pilgrims to the mosque to attend religious studies from various professions such as lecturers at Halu Oleo University, students and their students, and residents.

In addition to radio media, the da'wah media through television developed by ICM also further expanded the reach of their da'wah. In the city of Kendari and its surroundings, there is a brother (as the ICM network) is a cable television network entrepreneur in Kendari City, offering cable television channels to ICM for use as a media for propaganda activities. Through this local TV broadcasting, the community can get dakwah access more quickly and more satisfying especially among mothers who do many activities inside the house. Another propaganda media is the humanitarian 05 aid ship from AMCF (Asian Muslim Charity Foundation) owned by ICM in, which has been operating since April 20, 2018, which was handed over directly by AMCF's leading donor Syehk Dr. Muhammad Al-Khoory. The area of

\footnotetext{
${ }^{20}$ Saprillah Syahrir, 'The Islamic Centre of Muadz Bin Jabal of Kendari', JICSA, Vol. 6, no. 2 (2017), p. 317.

${ }^{21}$ Interview with Ustadz Anwar, Ustadz Syamsul, and Ustadz Heru.
} 
operation of this humanitarian ship is the islands that are difficult to reach by land vehicles such as Labengki and the surrounding areas which are tourist islands in the North Konawe district, as well as the Laonti area of Konawe Regency. This humanitarian ship carries out humanitarian activities in the form of health assistance, cheap food assistance, fostering preaching to the community and children, so the coastal community always await for it. ${ }^{22}$

In addition to supporting media publications, ICM has several infrastructures in the form of mosque buildings and exclusive learning spaces. With funding from Saudi Arabian donors, local donors and community infaq, ICM continues to develop and even add pesantren locations on waqf land in the areas of South Konawe, Konawe, Kolaka, East Kolaka, and Wakatobi. ICM even began to develop a network to areas outside the island of Sulawesi, namely Raja Ampat, West Papua and Bandung, West Java. The development in Raja Ampat did not get constrained even though its development was not as good as Kendari. Whereas the construction of the Wakatobi ICM had faced obstacles from the local parties with accusations addressed to ICM as a Wahabi and ISIS network. Another concern is that ICM seems as "damaging" the existence of the Babussalam pesantren in the area, although these concerns have gradually disappeared.

ICM was established to invite Muslims to purify worship and exemplary the Prophet Muhammad and supporting the government in building the nation's morality based on the Qur'an and Sunnah, able to gain sympathy from the people of Kendari City in a relatively short time. The interest of the people who become active worshipers of ICM activities is a phenomenon that shows the progress of the ICM, apart from the completeness of infrastructure, the whole level of education, and the maximum pattern and media of da'wah from radio, television and blog media. ${ }^{23}$

The development of ICM is very quickly, influenced by internal and external factors. Internally, ICM is supported financially by Saudi Arabian donors. Also, ICM has a more open relationship with the government and society, different from the pattern that is commonly used which seems closed and keeps a distance from the government and society. In the process of learning, communication and development networks, it is divided into two groups, first, salafi which experiences accelerated development individually and in groups, namely salafi which follows the wishes of the people and the government. Muadz bin Jabal's Islamic Center falls into this category because ICM manages its management with principled ideals (mis̄äliyah and wäqi iyah). ICM received a response from the people of Kendari city so well because it provided teaching opportunities to all levels of society, ranging from academics, traders, medical personnel, the general public. Able to be invited voluntarily without coercion and violence, so that many people feel gain satisfaction and comfort when joining the ICM. Secondly, another form of salafi in Kendari, salafi which reluctant to follow the trend of society, so its impression imposes on society. They even criticized the ICM and considered them to be extravagant compared to the dakwah of salaf al-

${ }^{22}$ Interview with Mr. Anwar in TV Muaz, December 18, 2018.

${ }^{23}$ Zainal, Suud and Zainal, 'Pola Pendidikan dan Pola Dakwah Islamic Centre Muadz Bin Jabal (ICM) di Kota Kendari’, Al-Izzah: Jurnal Hasil-Hasil Penelitian, Vol. 12, no. 2 (2018), p. 48. 
șälih, which was full of simplicity, not necessarily having the facilities obtained by selling its ideology and piety. Therefore, this group is developing slowly, both in terms of individual community support as well as the local government.

Externally, ICM is in the public interest because it brings a new color of education and da'wah compared to other existing groups such as NU and Muhammadiyah. Besides, social and cultural factors have a significant influence. Kendari people have historically been slow in getting religious knowledge as in other regions. Thus forming the face of Islam as it is, which does not socially and culturally have active religious militancy, so there are no Islamic boarding schools, especially older kyai (Islamic expert) who have strong character and become the primary reference for the community, this is also due to a large number of migrant communities with different backgrounds.

Socially, the absence of figures and pesantren with a strong character which is the primary reference for Kendari people causes the weakness of religious principles to be weak so that people tend to be able to accept something new and appreciate it in any form as long as it does not conflict with their culture.

With high financial capacity, ICM builds a complete infrastructure and runs extensive and intense education and $d a^{\prime} w a h$ programs by utilizing modern media such as radio, television, internet, and social media. ${ }^{24}$ Although carrying ideas or ideologies that tend to be alien to the Kendari community, ICM only need one year to show tremendous progress in gaining the interest of Muslims to entrust their children's education to ICM. ${ }^{25}$ Even the ICM has been able to take over the role of many other religious institutions that have existed before in Kendari. ${ }^{26}$

As part of the adherents of the Salafi, ICM considers tasfiyah (purification) of Islamic teachings amid Indonesian Muslims to be urgently needed because religious beliefs and practices-Including Kendari-are not following the understanding of the Salaf as the ideal generation. They want to teach them right, clean and straight Islamic aqidah because among the Kendari community they have erroneous creeds such as Shia and Ahmadiyah. Besides, some religious practices that do not have the basis on the Qur'an and the Sunnah such as the tradition of reading the Barzanji and the Maulidan program. ${ }^{27}$

${ }^{24}$ Zainal, Suud and Zainal, 'Pola Pendidikan dan Pola Dakwah Islamic Centre Muadz Bin Jabal (ICM) di Kota Kendari', Al-Izzah: Jurnal Hasil-Hasil Penelitian, Vol. 12, no. 2 (2018), p. 44.

${ }^{25}$ Nur Alim and others, 'Singularitas Agama: Identifikasi Aliran dan Paham Radikal di Kendari', Al-Ulum, Vol. 18, no. 2 (2019), p. 271-300.

${ }^{26}$ Zainal, Suud and Zainal, 'Pola Pendidikan dan Pola Dakwah Islamic Centre Muadz Bin Jabal (ICM) di Kota Kendari', Al-Izzah: Jurnal Hasil-Hasil Penelitian, Vol. 12, no. 2 (2018), p. 48.

${ }^{27}$ Nur Alim and others, 'Singularitas Agama: Identifikasi Aliran dan Paham Radikal di Kendari', Al-Ulum, Vol. 18, no. 2 (2019), p. 290. 


\section{ICM and social-religious dynamics of Muslim Kendari}

Changes in attitudes and behavior of the people are never separated from the transfer of knowledge into a new social transformation for followers and groups with the existence of rules or values and norms in life. The change is more directed to the principles of religious life, practice, and culture in the social life of the community.

The presence of the ICM salafi in Kendari City with a variety of new ideas and teachings gave rise to socio-religious discourse in the community, especially religious leaders and members of other religious organizations. For example, it was stated by a committee of the Masjid Al-Kautsar ${ }^{28}$ (Grand Mosque of Southeast Sulawesi Province):

"The existence of Salafi with ICM is disturbing the community. They come together in the congregation at the mosque, and their practices are different from the majority community. After the prayer, there is no wirid reading, and there is no prayer. Many laypeople ask because they think it is strange because it is different from the majority habits that have been rooted for generations in the hearts of Kendari people." 29

Besides, ICM has contributed significantly to the changes of the social life in the community, for example, the tradition of thanksgiving, wedding traditions, memorial traditions of maulid/isra 'mi'raj, dress tradition, and usury-free (riba) residential communities.

a. The reading tradition of Barzanji and Surah Yasin

The tradition of thanksgiving in the practice of the Muslim community of Kendari is a symbol of tabarruk. Tabarruk is to find blessings for developing and increasing goodness. A Muslim believes that this blessing is given by Allah to a being who is good at blessing Allah's favors. Allah is the source of blessing for every human action done facing the earth in seeking rizki (treasure). The real activity for the community in carrying out the thanksgiving is by carrying out the tradition of reading the book al-Barzanji or reading the Surah Yasin in the congregation or calling the cleric or the imam praying for the celebration of thanksgiving in question. Salafi's view of the thanksgiving program is very different because gratitude does not need to use the book Barzanji in expressing it, even such things are considered heresy or those deeds are deeds that are considered exaggerating because there is no connection between the book and the feeling thanksgiving. Salafi removes many prayers and practices to be able to reach Allah (tawassul).

The presence of Salafi has shifted the view, and the Barzanji and Yasinan groups of people have left the tradition because they understand it as a heresy.

b. Wedding tradition

${ }^{28}$ This mosque is a great mosque that should be open for use by anyone, including by Salafi followers who often try to make it a place of recitation. It's just rejected by the committee based on the advice of a number of worshipers who feel uncomfortable. Interview with Abdul Wahid as a manager of Masjid Al-Kautsar Kendari, March 11, 2016.

${ }^{29}$ Interview with Abdul Wahid as a manager of Masjid Al-Kautsar Kendari, March 11, 2016. 
The Kendari wedding tradition is open to many tribes, where the community is given the freedom to use their respective traditions, even though Islamic Sharia is still applied in the process of being approved. The Tolaki, Buton, Bugis, Muna, and others respect and understand each other's customs as long as they do not burden both parties. In this tradition there are many things are different from the traditions of the era of the Prophet Muhammad and the companions of the Prophet. These differences underlie the emergence of a negative response from adherents of the salafi sect in Kendari.

The tradition of reciting the Qur'an and the arrangement of the position of the bride and the invited guests at a wedding reception are examples of things highlighted by Salafi. The tradition that has taken root in the Kendari community is claimed to violate the teachings of Islam, so it needs to be revised. So, some followers and new worshipers of ICM and other salafis immediately changed their traditions and followed the teachings of Salafi by abolishing events such as reciting the verses of the Qur'an and reconstructing the reception model as well as the old tradition. Salafis in Kendari try to dismantle the tradition even though it is cultural acculturation with Islam because it is part of the purification of the religion they are holding.

c. Istigāisah tradition

The Islamic community (especially NU followers) in Kendari has an istigāisah tradition of gathering together in congregations involving clerics and religious teachers who are considered to have more abilities than ordinary people. The community joined in to follow, which became the guidance of the istigāisah. The people of Kendari call it differently, sometimes using tabligh akbar or pengajian akbar, but for salafi it is not permissible to do istigāisah because such things do not have a basis on the Qur'an and Sunnah. Moreover, the istigāisah tradition is a tradition of followers of the tarekat which always sends various prayers to the founders and their murshids. Salafi's view of what the Sufis and murshids do is a very far-reaching heresy because they still believe in tawassul so that the istigāiah tradition always sends these various prayers as deviations. Salafi's view from the outset is to put back the purification of the faith by assuming that the person who had died had not been exaggerated, let alone be overly prayed for and this would have been too long if it had caused the person who treated those who had died too long.

d. Shari'a property free from riba (usury)

The housing business in Kendari City has experienced rapid progress in recent years. Housing development is synonymous with cooperation with conventional banks in funding. The anti-usury group firmly refused to use conventional bank funding and tried to find a non-usury alternative called sharia banks. The use of funds from sharia banks underlie the term 'perumahan syariah'30

ICM also gives influence to the people of Kendari because its followers held housing with no usury credit, so it is claimed to be based on Sharia which has not been done by other groups. Housing loans that they have built as many as

\footnotetext{
${ }^{30}$ Egi Arvian Firmansyah and Deru R Indika, 'Kredit Pemilikan Rumah Syariah Tanpa Bank: Studi di Jawa Barat', Jurnal Manajemen Teori dan Terapan | Journal of Theory and Applied Management, Vol. 10, no. 3 (2017), p. 223.
} 
approximately 20 housing units are welcomed by pilgrims who are indeed looking for non-usury housing alternatives. The anti-usury community thinks that shari' $a$ housing (perumahan syariah) that has existed so far using Shari'a banks as a funding base is still considered still contain usury, so the best alternative is housing without going through bank financing. The congregation of the ICM salafi takes this alternative with a voluntary system, where among them they become donors and built special housing and run their credit system independently which is different from the banking system, both conventional and sharia.

The useless house program developed by ICM and its congregation received good responses from the Muslim community which proved to be overwhelmed by the supply of units due to a large number of worshipers interested in ordering the housing. This became a way for ICM to spread understanding and attract the sympathy of the Kendari Muslim community. The program that continues to be developed has formed a separate social segregation in the Kendari community because socially they live with fellow Salafis and are limited in association with other groups.

\section{E. Conclusion}

Salafi, as a new religious understanding in Indonesia, has significant implications for the socio-religious change of the Kendari community. The idea of salafi which has initially been simple was spread through educational institutions and community organizations such as the Pesantren Minhajussunnah and Wahdah Islamiyah, developing significantly with the presence of the Islamic Center Muadz bin Jabal (ICM) which massively spread the understanding of salafi. The typology of the Wahdah Islamiyah salafi movement is included in the 'purist tanzimi' category, while the ICM and Minhajussunnah salafi movements are included in the 'purist cooperationist' category. ICM has a special and great potential, which is financial support from Saudi Arabian donors that are used to develop infrastructure and professional education programs so that they quickly gain sympathy from the public. The adherents of the salafi have only shifted from religious ideas and organizations that existed before while leaving behind some practices and their socio-religious culture. The program barzanji, shalawatan, istigāisah, the ritual of marriage is abandoned, including the fashion style changing to the character salafi and social segregation among other Muslims. Even the property and finance fields were also affected, such as the presence of special Sharia-labeled housing. This confirms that religious understanding influences the social life of the community. 


\section{BIBLIOGRAPHY}

Al-'Ashimi, Mu'tab bin Suryan, Beda Salaf Dengan Salafi (Solo: Media Islamika, 2007)

Alim, Nur, Pairin Pairin, Muh Ikhsan, Samrin Samrin and Syamsuddin Syamsuddin, 'Singularitas Agama: Identifikasi Aliran Dan Paham Radikal Di Kendari', AlUlum, 18 (2019), 271-300 <https://doi.org/10.30603/au.v18i2.487>

Baz, Mira, 'Lebanese Salafis between the Gulf and Europe: Development, Fractionalization and Transnational Networks of Salafism in Lebanon', Islam and Christian-Muslim Relations, 25 (2014), 134-36 <https://doi.org/10.1080/09596410.2013.841348>

Bungin, Burhan, Sosiologi Komunikasi; Teori, Paradigma Dan Diskursus Teknologi Komunikasi Di Masyarakat, IV (Jakarta: Kencana Prenada Media Group, 2009)

Firmansyah, Egi Arvian and Deru R Indika, 'Kredit Pemilikan Rumah Syariah Tanpa Bank: Studi Di Jawa Barat', Jurnal Manajemen Teori Dan Terapan | Journal of $\begin{array}{lllll}\text { Theory and Applied } & \text { Management, } 10 & \text { (2017), } 223\end{array}$ <https://doi.org/10.20473/jmtt.v10i3.6541>

Hadi, Mukhtar, 'Fenomena Kelompok Keagamaan Baru (Heresy) Dalam Islam (Studi Terhadap Jama'ah Ittiba' Al -Salaf Di Purwoasri Metro Utara)', Ri'ayah, 2 (2017), 1-19

Haykel, Bernard, Revival and Reform in Islam: The Legacy of Muhammad AlShawkani (UK: Cambridge University Press, 2003)

Ma'arif, Syamsul, 'Ideologi Pesantren Salaf: Deradikalisasi Agama Dan Budaya Damai', IBDA ' : Jurnal Kajian Islam Dan Budaya, 12 (2014), 198-209

Misbah, Muhammad, 'Tradisi Keilmuan Pesantren Salafi', IBDA': Jurnal Kajian Islam Dan Budaya, $12 \quad$ (2014), <https://doi.org/10.24090/ibda.v12i2.449>

Muradi, Gerakan Paderi Di Sumatera Barat (Jakarta: Logos, 1999)

Rahmat, M. Imdadun, Arus Baru Islam Radikal Transmisi Revivalisme Islam Timur Tengah Ke Indonesia (Jakarta: Erlangga, 2005)

Syahrir, Saprillah, 'The Islamic Centre of Muadz Bin Jabal of Kendari', JICSA, 6 (2017), 295-331.

Thalib, Ja 'far Umar, 'Pasang Surut Menegakkan Syariah Islamiyah', Majalah SALAFY, 5, 664-702

Al Thalibi, Abu Abdirrahman, Dakwah Salafiyah Dakwah Bijak: Meluruskan Sikap Keras Dai Salafi (Jakarta: Hujjah Press, 2006), I

Wahid, Din, 'Nurturing Salafi Manhaj A Study of Salafi Pesantrens in Contemporary $\begin{array}{llll}\text { Indonesia', } & \text { Wacana, } & 15 & \text { (2015), }\end{array}$ 
<https://doi.org/10.17510/wacana.v15i2.413>

Wiktorowicz, Quintan, 'Anatomy of the Salafi Movement', Studies in Conflict and Terrorism, 29 (2006), 207-39 <https://doi.org/10.1080/10576100500497004>

Woodward, Mark, 'Modeling Muslim Social Movements: A Case Study of Indonesian Salafism', in Annual Conference on Islamic Studies Banjarmasin Indonesia, 2011, pp. 1-16

Zainal, Asliah, Sudarmi Suud and Asrianto Zainal, 'Pola Pendidikan Dan Pola Dakwah Islamic Centre Muadz Bin Jabal (ICM) Di Kota Kendari', Al-Izzah: Jurnal Hasil-Hasil Penelitian, $12 \quad$ (2018), 44 <https://doi.org/10.31332/ai.v12i2.640> 


\section{Guidelines}

\section{Submission of Article}

urnal Adabiyah welcomes the articles submission with the main themes on Humanities and Islamic Studies with the emphasis on interdisciplinary and intertextuality approach. Adabiyah is thematicly published twice in a year. ie the theme of the humanities in June and the Islamic Study in December.

Themes related to Islamic Studies are textual studies, scriptural traditions, Islamic law, and theology; and those related to Humanities are language, literature, history, and culture. This scholarly journal Guarantees that the editor decision based on the peer review results will not exceed 30 days from the paper submission date.

Authors are invited to read our archives; to find the relevant topics for the journal, and to submit complete unpublished scientific researches, which are not under review in any other conferences or academic journal.

\section{PUBLICATION ETHIC}

Publication Ethic and Malpractice Statement

Jurnal Adabiyah is a peer-reviewed journal, published twice a year by the Faculty of Adab and Humaniora, Alauddin State Islamic University of Makassar Indonesia. It is available online as open access sources as well as in print. This statement clarifies ethical behaviour of all parties involved in the act of publishing an article in this journal, including the author, the editor-in-chief, the Editorial Board, the reviewers, and the publisher. This statement is based on COPE's Best Practice Guidelines for Journal Editors.

Ethical Guideline for Journal Publication

The publication of an article in Jurnal Adabiyah, is an essential building block in the development of a coherent and respected network of knowledge. It is a direct reflection of the quality of the work of the authors and the institutions that support them. Peer-reviewed articles support and embody the scientific methods. It is therefore important to agree upon standards of expected ethical behavior for all parties involved in the act of publishing: the author, the editor, the reviewer, the publisher, and the society. As the publisher of Jurnal Adabiyah, the Faculty of Adab and Humaniora takes its duties of guardianship over all stages of publishing seriously and it recognizes its ethical and other responsibilities. The Faculty of Adab and Humaniora committed to ensuring that advertising, reprint or other commercial revenue has no impact or influence on editorial decisions.

\section{Publication Decisions}

The editors of Jurnal Adabiyah is responsible for deciding which articles submitted to the journal should be published. The validation of the work in question and its importance to researchers and readers must always drive such decisions. The editors may be guided by the policies of the journal's editorial board and constrained by such legal requirements as shall then be in force regarding libel, copyright infringement, and plagiarism. The editors may confer with other editors or reviewers in making their decisions.

\section{Plagiarism Screening}

It is basically author's duty to only submit a manuscript that is free from plagiarism and academically malpractices. The editor, however, will check all submitted papers through Turnitin.

\section{Fair Play}

An editor at any time evaluates manuscripts for their intellectual content without regard to race, gender, sexual orientation, religious belief, ethnic origin, citizenship, or political philosophy of the authors. 


\section{Confidentiality}

The editors and any editorial staff must not disclose any information about a submitted manuscript to anyone other than the corresponding author, reviewers, potential reviewers, other editorial advisers, and the publisher, as appropriate.

\section{Disclosure and Conflicts of Interest}

Unpublished materials disclosed in a submitted manuscript must not be used in editors' own research without the express written consent of the author.

\section{DUTIES OF AUTHORS}

\section{Reporting Standards}

Authors of reports of original research should present an accurate account of the work performed as well as an objective discussion of its significance. Underlying data should be represented accurately in the paper. A paper should contain sufficient detail and references to permit others to replicate the work. Fraudulent or knowingly inaccurate statements constitute unethical behaviour and are unacceptable.

\section{Originality and Plagiarism}

The authors should ensure that they have written entirely original works, and if the authors have used the work and/or words of others that this has been appropriately cited or quoted.

\section{Multiple, Redundant, or Concurrent Publication}

An author should not in general publish manuscripts describing essentially the same research in more than one journal or primary publication. Submitting the same manuscript to more than one journal concurrently constitutes unethical publishing behaviour and is unacceptable.

\section{Acknowledgement of Sources}

Proper acknowledgment of the work of others must always be given. Authors should cite publications that have been influential in determining the nature of the reported work.

\section{Authorship of the Paper}

Authorship should be limited to those who have made a significant contribution to the conception, design, execution, or interpretation of the reported research. All those who have made significant contributions should be listed as co-authors. Where there are others who have participated in certain substantive aspects of the research project, they should be acknowledged or listed as contributors. The corresponding author should ensure that all appropriate co-authors and no inappropriate co-authors are included on the paper, and that all co-authors have seen and approved the final version of the paper and have agreed to its submission for publication.

\section{Disclosure and Conflicts of Interest}

All authors should disclose in their manuscript any financial or other substantive conflict of interest that might be construed to influence the results or interpretation of their manuscript. All sources of financial support for the project should be disclosed.

\section{Fundamental errors in Published Works}

When an author discovers a significant error or inaccuracy in his/her own published work, it is the author's obligation to promptly notify the journal editor or publisher and cooperate with the editor to retract or correct the paper.

\section{PLAGIARISMI}

It is basically author's duty to only submit a manuscript that is free from plagiarism and academically malpractices. The editor, however, will check all submitted papers through Turnitin. 


\section{AUTHOR GUIDELINES}

\section{Guidelines for online submission:}

1. Author should first register as Author to the website of Jurnal Adabiyah. Click the menu "register" to register as an author.

2. Once after the author is registered, please login to the website of Jurnal Adabiyah and submit the article through online submission (with the stat us of active submissions).

3. The article should follow the standard template of Jurnal Adabiyah provided in the website.

4. The citation and bibliography should follow the Turabian citation style.

5. Author is restricted not to send his/her article to another journal before having confirmation from the editorial team (approximately 4 weeks right after the article submitted).

6. Author should follow editorial decisions and recommendations related to the article completion. All reviews and assessements will be informed through online submission.

Article submitted to Jurnal Adabiyah editorial board must follow these guidelines:

1. Article should be based on the scientific research in the field humanities and Islamic studies;

2. Article must be an original work and has not been previously published;

3. Article should be written in Arabic or English languages;

4. Article must be typed in one-half spaced on A4-paper size;

5. Article's length is about $6,000-10,000$ words;

6. All submission must include a 150-250 word abstract;

7. Abstract should be written in 3 languages; Arabic, English, and Bahasa;

8. Full name(s) of the author(s) must be stated, along with his/her/their institution and complete address;

9. All submission should be in OpenOffice, Microsoft Word, RTF, or WordPerfect document file format;

10. Bibliographical reference must be noted in footnote and bibliography according to Jurnal Adabiyah style. In addition, it is suggested for author(s) to use reference manager tools such as 30 MENDELEY or 2 otero

When a source is cited for the first time, full information is provided: full name(s) of author(s), title of the source in italic, place of publication, publishing company, date of publication, and the precise page that is cited. For the following citations of the same source, list the author's last name, two or three words of the title, and the specific page number(s). The word ibid., op.cit., and loc.cit. are may not be used any more.

\section{Example in footnotes:}

${ }^{1}$ Mircea Eliade (ed.), The Encyclopedia of Religion, vol. 8 (New York: Simon and Schuster, 1995), h. 18.

${ }^{2}$ Norman Daniel, Islam and the West (Oxford: One World Publications, 1991), h. 190.

${ }^{3}$ Syeikh Ja'far Subhānī, Mafăhim Al-Qur'ān (Beirut: Mu'assasah Al-Tarikh Al-'Arabī, 2010)., Juz 5, h. 231. 
${ }^{4}$ Syeikh Ja'far Subhānī, Mafăhim Al-Qur'ān, h. 8-9.

\section{Example in bibliography:}

Subhānī, Syeikh Ja'far. Mafāhim Al-Qur'ān. Beirut: Mu'assasah Al-Tarikh Al-'Arabī, 2010.

Eliade, Mircea (ed.). The Encyclopedia of Religion, vol. 8. New York: Simon and Schuster, 1995.

Daniel, Norman. Islam and the West. Oxford: One World Publications, 1991.

Shihab, Muhammad Quraish. Sunnah-Syiah Bergandengan Tangan: Mungkinkah? Kajian Atas Konsep Ajaran Dan Pemikiran. Cet. III. Jakarta: Lentera Hati, 2007.

Detail informations of the footnotes:

1. Holy book

Al-Qur'ân, Al-Baqarah/2: 185.

Perjanjian Baru, Mrk. 2: 18.

2. Qur'anic translation

${ }^{1}$ Departemen Agama RI, al-Qur'an dan Terjemahannya (Jakarta: Darus Sunnah, 2005), h. 55.

3. Book

${ }^{1}$ Muḥammad 'Ajjaj al-Khațib, Ușl al-Hadith: 'Ulumuh wa Mușțalaḥuh (Beirut: Dâr al-Fikr, 1989), h. 57.

4. Translation Books

${ }^{1}$ Toshihiko Izutsu, Relasi Tuhan dan Manusia: Pendekatan Semantik terhadap al-Qur'an, terj. Agus Fahri Husein dkk (Yogyakarta: Tiara Wacana, 2003), h. 14.

5. Voluminous book

${ }^{1}$ Muḥammad al-Ṭâhir b. 'Ashur, al-Tạnn̄̄r wa al-Tanwīr, Vol. 25 (Tunisia: Dâr al-Suhûn, 2009), h. 76.

${ }^{1}$ Muḥammad b. Ismā‘īl al-Bukharī, al-Jami` al-Ṣahịḥ, Vol. 2 (Beirut: Dar al-Kutub al-‘Ilmìyah, 1999), h. 77.

6. Article in book

${ }^{1}$ Sahiron Syamsuddin, "Metode Intratekstualitas Muhammad Shahrur dalam Penafsiran al-Qur'an" dalam Abdul Mustaqim dan Sahiron Syamsuddin (eds.), Studi al-Qur'an Kontemporer: Wacana Baru Berbagai Metodologi Tafsir (Yogyakarta: Tiara Wacana, 2002), h. 139.

7. Article in encyclopaedia

${ }^{1}$ M. Th. Houtsma, "Kufr” dalam A. J. Wensinck, at al. (ed.), First Encyclopaedia of Islam, Vol. 6 (Leiden: E.J. Brill, 1987), h. 244.

8. Article in journal

${ }^{1}$ Muhammad Adlin Sila, "The Festivity of Maulid Nabi in Cikoang, South Sulawesi: Between Remembering and Exaggerating the Spirit of Prophet", Studia Islamika 8, no. 3 (2001): h. 9.

9. Article in mass media

${ }^{1}$ Masdar F. Mas'udi, "Hubungan Agama dan Negara", Kompas, 7 Agustus 2002. 
10. Article in Internet

${ }^{1}$ Muhammad Shahrūr, "Reading the Religious Teks: a New Approach" dalam http://www.shahrour.org/25 Februari 2010/diakses 5 Juni 2010.

11. Thesis or dissertation

${ }^{1}$ Syahruddin Usman, "KinerjaGuru Penddikan Agama Islam pada SMAN dan SMKN Kota Makassar”, Disertasi (Makassar: PPs UIN Alauddin, 2010), h. 200.

\section{COPYRIGHT NOTICE}

Authors who publish with this journal agree to the following terms:

1) Authors retain copyright and grant the journal right of first publication with the work simultaneously licensed under a Creative Commons Attribution License that allows others to share the work with an acknowledgement of the work's authorship and initial publication in this journal.

2) Authors are able to enter into separate, additional contractual arrangements for the non-exclusive distribution of the journal's published version of the work (e.g., post it to an institutional repository or publish it in a book), with an acknowledgement of its initial publication in this journal.

3)Authors are permitted and encouraged to post their work online (e.g., in institutional repositories or on their website) prior to and during the submission process, as it can lead to productive exchanges, as well as earlier and greater citation of published work (See The Effect of Open Access). 